\title{
Uptake and speciation of vanadium in the rhizosphere soils of rape (Brassica juncea L.)
}

\author{
Li-Yan Tian • Jin-Yan Yang • Jen-How Huang
}

Received: 3 September 2014 / Accepted: 19 December 2014 / Published online: 15 January 2015

(C) Springer-Verlag Berlin Heidelberg 2015

\begin{abstract}
The response of rape (Brassica juncea L.) to different vanadium $(\mathrm{V})$ speciation in rhizosphere soils was investigated in pot experiments using an agricultural soil containing $147 \mathrm{mg} \mathrm{V} \mathrm{kg}^{-1}$ supplemented with $0-500 \mathrm{mg} \mathrm{V} \mathrm{kg}^{-1}$ of pentavalent $\mathrm{V}[\mathrm{V}(\mathrm{V})]$ and a mining soil containing $774 \mathrm{mg} \mathrm{V} \mathrm{kg}{ }^{-1}$. Tetravalent $\mathrm{V}$ [V(IV)] accounted for 76.1 and $85.9 \%$ of total $\mathrm{V}$ in the untreated agricultural soil and mining soil, respectively. The proportion of both $\mathrm{V}(\mathrm{V})$ and water-extractable $\mathrm{V}$ increased with increasing concentrations of $\mathrm{V}(\mathrm{V})$ in the agricultural soil. The growth of rape substantially reduced the concentrations of $\mathrm{V}(\mathrm{V})$ but not $\mathrm{V}(\mathrm{IV})$ in the rhizosphere soil, suggesting that $\mathrm{V}(\mathrm{V})$ was actively involved in the soil-rape interaction of V. Both soil V(V) and waterextractable $\mathrm{V}$ were negatively related to the total rape biomass, but were positively correlated with the concentration of root $\mathrm{V}$. No such relationships were found for total V and soil V(IV). Together, these results indicate that soil $\mathrm{V}(\mathrm{V})$ and waterextractable $\mathrm{V}$ might better reflect the toxicity of $\mathrm{V}$ in soils than total V and soil V(IV). Rape accumulated V in the sequence: roots $>>$ stem $>$ leaf $>$ seed. As indicated by the remarkably low root bioconcentration factor of $\mathrm{V}(\mathrm{V})(0.41-7.24 \%)$, rape had a lower ability to accumulate $\mathrm{V}$ than other plants reported in the literature (14.6-298\%). Only a small fraction of V in rape roots was translocated to the aboveground organs (the translocation factor was 3.57-46.9\%). No V was detectable in seeds in the soils at 147 and $197 \mathrm{mg} \mathrm{V} \mathrm{kg}^{-1}$, and no seed
\end{abstract}

Responsible editor: Elena Maestri

L.-Y. Tian · J.-Y. Yang $(\bowtie)$

College of Architecture and Environment, Sichuan University,

Chengdu 610065, China

e-mail: yanyang@scu.edu.cn

L.-Y. Tian · J.-H. Huang $(\bowtie)$

Environmental Geosciences, University of Basel, CH-4056, Basel, Switzerland

e-mail: jen-how.huang@unibas.ch was produced in the soils at higher $\mathrm{V}$ concentrations. Thus, the risk of $\mathrm{V}$ intake by humans via the consumption of rapeseedbased foods under normal conditions is considered to be lower than that of other plants.

Keywords Vanadium · Speciation . Rape (Brassica juncea L.) · Agricultural soil · Mining soil · Rhizosphere

\section{Introduction}

Vanadium (V) is a trace element that is widely distributed in the environment (Pyrzyńska and Wierzbicki 2004), and its global mean concentration in soils is about $150 \mu \mathrm{g} \mathrm{g}^{-1}$ (Panichev et al. 2006). High concentrations of V in the surface environment are usually directly associated with anthropogenic inputs, e.g. the burning of fossil fuel, and the steel, aluminium and alloy industry (Burke et al. 2013; Vwioko et al. 2006) and the concentration of $\mathrm{V}$ in soils can reach $0.1 \%$ at contaminated sites (Teng et al. 2011). Vanadium in soils is generally poorly mobile. Both sequential extraction and columnleaching experiments indicated that usually less than $1 \%$ of total $\mathrm{V}$ in soils is extractable and leachable with water (Larsson et al. 2013; Teng et al. 2009; Yang et al. 2014b). The high proportion of $\mathrm{V}$ found in the residual fraction of sequential extractions might be related to the general predominance of V(IV) in soils (Baken et al. 2012; Mandiwana and Panichev 2004; Tian et al. 2014; Yang et al. 2014b), which is a less mobile and toxic form of $\mathrm{V}$ than pentavalent $\mathrm{V}(\mathrm{V})$ (Baken et al. 2012).

Vanadium has been identified as an essential micronutrient for living organism such as green algae (Nalewajko et al. 1995), several species of fungi and nitrogen-fixing 
microorganisms (Anke 2004). However, excessive V can lead to substantial toxic effects (Carlson et al. 1991; Kaplan et al. 1990; Qian et al. 2014; Tian et al. 2014; Wang and Liu 1999). Excess V in the human body can increase the risk of lung cancer and also cause nausea, mild diarrhoea and stomach cramps (ATSRD 2012). High concentrations of V in nutrient solution and soils can cause changes in the root and leaf morphology of plants and more seriously lead to the complete inhibition of plant growth (Saco et al. 2012; Tian et al. 2014; Yang et al. 2014a). Moreover, high concentrations of V(V) in red mud-contaminated soils and leachates have been demonstrated to cause chromosomal damage in tetrads of Tradescantia and in root cells of Allium as well as retardation of root growth (Misik et al. 2014). Recently, an increasing number of studies have measured the influence of $\mathrm{V}$ in soils on plant growth; however, these studies have only focused on the total V concentration (Hou et al. 2013; Kaplan et al. 1990; Xiao et al. 2012; Yang et al. 2011). Most studies showed a similar increase in the inhibition of plant growth with increasing concentrations of total $\mathrm{V}$ in the soil. However, the toxicity threshold of total $\mathrm{V}$ in soils differs, depending strongly on the soil characteristics. Larsson et al. (2013) investigated the different toxicity threshold of total soil $\mathrm{V}$ by performing a series of toxicity tests of $\mathrm{V}$ on barley and tomato in different soil types. It was concluded that $\mathrm{V}$ toxicity in soils is controlled by the $\mathrm{V}$ sorption strength of the soil and $\mathrm{V}$ concentrations in soil solutions probably account for the toxicity of $\mathrm{V}$, instead of the total V content (Larsson et al. 2013).

To date, knowledge relating to the role of the pool size of water-extractable $\mathrm{V}$ and $\mathrm{V}$ oxidation states in soil-plant $\mathrm{V}$ interactions is still rare. Therefore, the aims of this study were (1) to assess the influence of oxidation state and water extractability of $\mathrm{V}$ in soils on the bioavailability and toxicity of $\mathrm{V}$ for rape (Brassica juncea L.) in agricultural and mining soils; (2) to understand the transformation and mobilisation of $\mathrm{V}$ in the rhizosphere soil during rape growth; (3) to analyse the ability of rape to accumulate and translocate $\mathrm{V}$ from the roots to the aboveground tissues. This study will extend knowledge to identify the potential risk of the human consumption of rape-based food materials.

\section{Materials and methods}

\section{Site description and soil sampling}

The sampling sites are located in the Panzhihua region, Sichuan province, SW China, where a large area has been polluted by $\mathrm{V}$ due to mining activities for vanadium titanomagnetite during the last half-century (Teng et al. 2011; Yang et al. 2014b). Top soils (0-20-cm depth) were sampled from an agricultural and a mining site, and both soil samples were homogenised, sieved to $2 \mathrm{~mm}$ and air-dried for rape growth experiments. The characteristics of the agricultural and mining soils are summarised in Table 1.

Experimental design and plant cultivation

All pot experiments were performed at a constant temperature of $\sim 25^{\circ} \mathrm{C}$, for a 14 -h photoperiod under full sun and at $\sim 20^{\circ} \mathrm{C}$ in the dark for $10 \mathrm{~h}$ with a relative humidity of $\sim 80 \%$ in a plant growth chamber (PRX-350A, Shanxi, China). Air-dried mining and agricultural soils $(2.5 \mathrm{~kg})$ were rewetted to a moisture content of $60 \%$ of field capacity in a polyethylene container with a diameter of $18.5 \mathrm{~cm}$ and a height of $13.5 \mathrm{~cm}$ and was incubated for a month to reactivate the microflora before planting. All pots were weighted daily and watered to $60 \%$ of field capacity continuously. After incubation, five different levels of $\mathrm{V}$ as $\mathrm{NaVO}_{3}$ solution were spiked into the agricultural soils, which were homogenised carefully, leading to increases in soil $\mathrm{V}$ concentrations of $0,50,100,150,250$ and $500 \mathrm{mg} \mathrm{V} \mathrm{kg}{ }^{-1}$. The soils were sealed with water-repellent bags and aged in pots for 12 months to approach partition equilibrium for the spiked V(V). Seeds of rape (from the Yunan Academy of Agricultural Science, China) were sown in the treated soils at a density of 20 seeds per pot. After germination, six plants in each pot were left for further growth. Three pots were prepared for each $\mathrm{V}$ concentration, and pots for all treatments were arranged randomly, and the positions were altered occasionally during incubation for 140 days. Each pot was weighted and irrigated daily to maintain a moisture content of roughly $60 \%$ field capacity in the soil.

Bulk soil samples were collected from each pot before rape planting, during seedling development and after harvesting, for the analysis of $\mathrm{V}(\mathrm{IV}), \mathrm{V}(\mathrm{V})$, total $\mathrm{V}$ and water-soluble $\mathrm{V}$. The soil samples taken after harvesting were divided into rhizosphere (soil associated with rape roots) and bulk soil samples, and these were air-dried and sieved to $2 \mathrm{~mm}$. The rape

Table 1 Characterisation of the agricultural and mining soils used in this study

\begin{tabular}{|c|c|c|}
\hline Parameters & Agricultural soil & Mining soil \\
\hline $\mathrm{pH}_{(\mathrm{H} 2 \mathrm{O})}$ & $7.95 \pm 0.07$ & $8.36 \pm 0.09$ \\
\hline $\mathrm{CEC}\left(\mathrm{cmol} \mathrm{kg}^{-1}\right)$ & $10.5 \pm 0.3$ & $15.8 \pm 0.01$ \\
\hline $\mathrm{TP}\left(\mathrm{mg} \mathrm{kg}^{-1}\right)$ & $295 \pm 36$ & $720 \pm 36$ \\
\hline Plant-available P ( $\left.\mathrm{mg} \mathrm{kg}^{-1}\right)$ & $13.1 \pm 0.8$ & $3.99 \pm 0.15$ \\
\hline Hydrolysable $\mathrm{N}\left(\mathrm{mg} \mathrm{kg}^{-1}\right)$ & $43.7 \pm 4.1$ & $31.7 \pm 6.9$ \\
\hline Organic matter $(\%)$ & $1.36 \pm 0.06$ & $1.15 \pm 0.24$ \\
\hline $\mathrm{V}\left(\mathrm{mg} \mathrm{V} \mathrm{kg}{ }^{-1}\right)$ & $147 \pm 7$ & $774 \pm 16$ \\
\hline Clay $(\%)$ & $7.91 \pm 1.70$ & $3.05 \pm 0.71$ \\
\hline Silt (\%) & $8.78 \pm 3.09$ & $7.80 \pm 0.99$ \\
\hline Sand $(\%)$ & $83.3 \pm 1.39$ & $89.2 \pm 1.6$ \\
\hline
\end{tabular}

Mean values and standard deviations of three replicates are shown $T P$ total phosphorus 
plants were harvested, rinsed carefully with de-ionised water and divided into seeds, leaves, stems and roots. Unless otherwise noted, all plant materials were air-dried in an oven at $105^{\circ} \mathrm{C}$ for $1 \mathrm{~h}$ and then at $70{ }^{\circ} \mathrm{C}$ to constant weight.

Quantification of total V in different parts of rape and soils

To quantify total $\mathrm{V}$, all plant materials were digested in a flask filled with a 8:1:1 $(v / v)$ mixture of $\mathrm{HNO}_{3}, \mathrm{H}_{2} \mathrm{SO}_{4}$ and $\mathrm{HClO}_{4}$ at $120-130^{\circ} \mathrm{C}$ for $5 \mathrm{~h}$ (Lu 1999). After cooling, the clear aliquot was diluted to $25 \mathrm{~mL}$ with de-ionised water for $\mathrm{V}$ analysis. To quantify total soil $\mathrm{V}$, a $0.1-\mathrm{g}$ soil fraction was heated with a mixture of concentrated $\mathrm{HF}, \mathrm{HNO}_{3}$ and $\mathrm{HClO}_{4}$ [12:1:2 $(v / v)]$ until completely dissolved. A Perkin-Elmer atomic absorption spectrophotometer model Analyst 800 (USA) was used for all measurements. A standard stock solution containing $1 \mathrm{~g} \mathrm{~L}^{-1} \mathrm{~V}$ (National Center of Analysis and Testing for Nonferrous Metals and Electronic Materials, China) was used for preparing standard solutions of 10, 20, 40, 80,160 and $200 \mu \mathrm{g} \mathrm{V} \mathrm{L}^{-1}$ in the corresponding sample matrix.

\section{Determination of water-extractable V in soils}

Approximately $1.0 \mathrm{~g}$ soil was mixed with $25-\mathrm{mL}$ de-ionised water in 50-mL plastic tubes and was shaken for $24 \mathrm{~h}$ at room temperature. After filtration (Minzheng No.202, GB/T 1914 2007, China), the supernatant was analysed for V using AAS (Mandiwana and Panichev 2004).

Speciation of tetravalent and pentavalent $\mathrm{V}$ in soils

Based on Mandiwana and Panichev (2004), $0.25 \mathrm{~g}$ of the soil samples was mixed with $25-\mathrm{mL} 0.1 \mathrm{M} \mathrm{Na}_{2} \mathrm{CO}_{3}$ in $50-\mathrm{mL}$ polypropylene Falcon tubes and was boiled for $15 \mathrm{~min}$. After cooling, the aliquots were filtered (Minzheng No.202, GB/T 1914-2007, China) for determination of V. This fraction of the soil $\mathrm{V}$ is pentavalent. The residue on the filter paper was transferred to a platinum crucible and ashed in a muffle furnace at $600{ }^{\circ} \mathrm{C}$ for $1 \mathrm{~h}$. The ash was digested with a 13:1 $(v / v)$ mixture of $\mathrm{HF} / \mathrm{HNO}_{3}$, and heated to near dryness. Thereafter, a 1:2 (v/ $v$ ) mixed solution was added and again evaporated to near dryness. After completely dissolving the residue with HF, $\mathrm{HNO}_{3}$ and $\mathrm{HClO}_{4}[12: 1: 2(v / v)]$, the aliquot was diluted to $25 \mathrm{~mL}$ with de-ionised water for $\mathrm{V}$ analysis. Because the residual solid holds $\mathrm{V}$ within the crystal structure of minerals, the concentration of $\mathrm{V}$ in the digest represents $\mathrm{V}(\mathrm{IV})$.

Speciation of $\mathrm{V}(\mathrm{V})$ and $\mathrm{V}(\mathrm{IV})$ in soils may be alternatively done using X-ray absorption spectroscopy (XAS) and chromatography-based analytical methods such as HPLCICP-MS coupling (Burke et al. 2013; Jensen-Fontaine et al. 2014; Li et al. 2009). However, chromatography-based speciation of $\mathrm{V}$ is still restricted to $\mathrm{V}$ extractable with mild extractants in soils, e.g. with water and EDTA solution, which is usually a very small fraction of total $\mathrm{V}$ in soils (Yang et al. 2014b). Due to lack of methods to preserve V species during extraction effectively, speciation of $\mathrm{V}$ in association with more refractory solid phrases in soils like the case of arsenic (Huang and Kretzschmar 2010) is still impossible. X-ray absorption spectroscopy may provide detailed information on the speciation and coordination environment of $\mathrm{V}$ in soils, provided that the concentrations are sufficiently high. However, in many soils and sediments, total $\mathrm{V}$ concentrations are too low for high-quality XAS measurements, and Ti concentrations are too high, which interfere largely with V-XAS measurements, particularly extended X-ray absorption fine structure spectroscopy measurements (Huang, personal communication). Therefore, most XAS speciation of V results in literature to date included only X-ray absorption near edge structure measurements (Burke et al. 2013; Shafer et al. 2012; Wong et al. 1984).

\section{Root bioconcentration and translocation factors}

The root bioconcentration factors were calculated as the ratio of the $\mathrm{V}$ concentration in the root to the concentration of $\mathrm{V}$ in the soil:

$\mathrm{BCF}_{\text {(root/soil) }}=\frac{\mathrm{C}_{\text {root }}}{\mathrm{C}_{\text {soil }}}$

The translocation factor of $\mathrm{V}$ from roots to leaves was represented as the ratio of the concentration of $\mathrm{V}$ in leaves to that in roots:

$\mathrm{TF}_{\text {(leaf/root) }}=\frac{\mathrm{C}_{\text {leaf }}}{\mathrm{C}_{\text {root }}}$

where $\mathrm{C}_{\text {soil }}$ is the $\mathrm{V}$ concentration in the soil, $\mathrm{C}_{\text {root }}$ is the $\mathrm{V}$ concentration in rape roots, and $\mathrm{C}_{\text {leaf }}$ is the $\mathrm{V}$ concentration in rape leaves (Qian et al. 2014).

Statistics

Data were processed using SPSS 16.0 and Microsoft excel 2003. For V concentrations in rape and soils, Duncan multiple comparison method was performed to analyse the significance between the differences at $p<0.05$. Pearson's correlation indexes between the rape biomass, the concentration of $\mathrm{V}$ in soil and rape, and the concentration of $\mathrm{V}(\mathrm{V})$ were calculated, and the significance was evaluated at $p<0.05$. 


\section{Results and discussion}

Vanadium speciation in the soils during rape growth

Speciation of soil $\mathrm{V}$ showed an exclusive predominance of $\mathrm{V}(\mathrm{IV})$ in the mining soil $(85.9 \%$ ) (Fig. 1a, b). In the agricultural soils, the proportion of V(IV) decreased with increasing concentrations of $\mathrm{V}(\mathrm{V})$ added. In the untreated agricultural soil, V(IV) represented $76.1 \%$ of the total V in the soil, whereas $\mathrm{V}(\mathrm{IV})$ was only $29.6 \%$ of total $\mathrm{V}$ in the soil at $647 \mathrm{mg} \mathrm{V} \mathrm{kg}^{-1}$. The speciation of $\mathrm{V}(\mathrm{IV})$ and $\mathrm{V}(\mathrm{V})$ did not change during rape growth (Fig. 1a, b). Accordingly, the

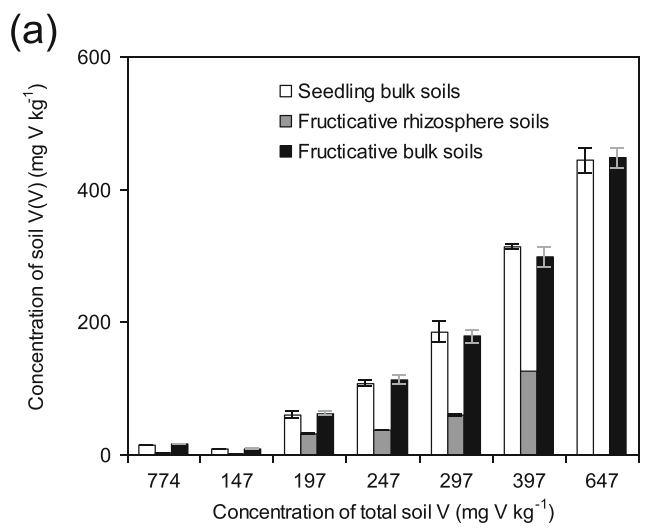

(b)

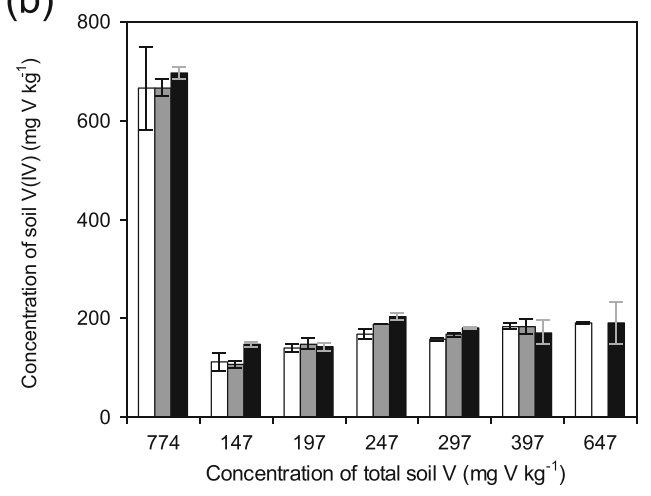

(c)

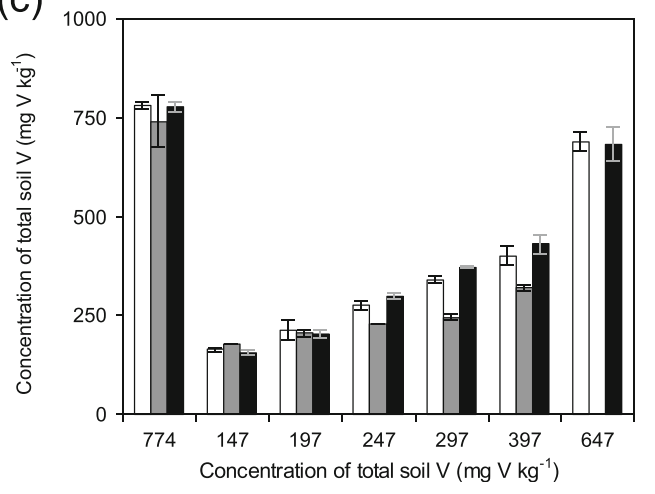

Fig. 1 Concentrations of a pentavalent vanadium (V(V)), b tetravalent (V(IV)) and $\mathbf{c}$ total vanadium in the rhizosphere and bulk soils in the agricultural and mining soils. Error bars show the standard deviations of three replicates natural geogenic $\mathrm{V}$ in the agricultural and mining soils was predominantly $\mathrm{V}(\mathrm{IV})$, whereas the added $\mathrm{V}(\mathrm{V})$ was stable for the duration of the pot experiment.

Notably, a significant decrease in the V(V) concentration was observed in the rhizosphere soils of all treatments compared to that of bulk soils $(p<0.05)$ (Fig. 1a). In contrast, there were no significant differences in the V(IV) concentrations in the rhizosphere and bulk soils. The decrease in $V(V)$ in the rhizosphere soils demonstrated that $\mathrm{V}(\mathrm{V})$ was the preferential $\mathrm{V}$ species taken up by rape and that $\mathrm{V}(\mathrm{V})$ is more mobile and more actively enters the biogeochemical cycle of $\mathrm{V}$ in the surface environment than V(IV) (Baken et al. 2012; Burke et al. 2012; Larsson et al. 2013). Similarly, V taken up in the benthic invertebrate Hyalella azteca in water exposed to air was also demonstrated to be mostly V(V). Namely, any V(IV) presented in water will be rapidly oxidised to $\mathrm{V}(\mathrm{V})$ under oxic conditions (Jensen-Fontaine et al. 2014).

The water-extractable $\mathrm{V}$ represented less than $4 \%$ of the total $\mathrm{V}$ in all soils (Table 2). In the agricultural soils, the proportion of water-extractable $\mathrm{V}$ increased with increasing concentrations of total $\mathrm{V}$, reflecting the increasing mobility of $\mathrm{V}$ in soils with an increasing concentration of added $\mathrm{V}(\mathrm{V})$. However, a similar positive relationship did not exist between the mining and agricultural soils. The pool of water-extractable $\mathrm{V}$ in the mining soil ( 0.28 and $0.29 \mathrm{mg} \mathrm{V} \mathrm{kg}^{-1}$ in the rhizosphere and bulk soil, respectively) was more than two-fold greater than in the original agricultural soil $\left(0.09\right.$ and $0.13 \mathrm{mg} \mathrm{V} \mathrm{kg}^{-1}$ in the rhizosphere and bulk soil, respectively), although the concentration of total $\mathrm{V}$ in the mining soil (774 $\mathrm{mg} \mathrm{V} \mathrm{kg}^{-1}$ ) was five times higher than that in the untreated agricultural soil (147 mg $\mathrm{V} \mathrm{kg}^{-1}$ ). Thus, total $\mathrm{V}$ alone cannot account for

Table 2 Concentrations of water-extractable vanadium (V) in the agricultural soils at different levels of $\mathrm{V}$ and in the mining soil

\begin{tabular}{cll}
\hline $\begin{array}{l}\text { Soil } \\
\left(\mathrm{mg} \mathrm{V} \mathrm{kg}^{-1}\right)\end{array}$ & $\begin{array}{l}\text { Bulk soil } \\
\left(\mathrm{mg} \mathrm{V} \mathrm{kg}^{-1}\right)\end{array}$ & $\begin{array}{l}\text { Rhizosphere soil } \\
\left(\mathrm{mg} \mathrm{V} \mathrm{kg}^{-1}\right)\end{array}$ \\
\hline $\begin{array}{l}\text { Agricultural soil } \\
147\end{array}$ & $0.13 \pm 0.02 \mathrm{dA}$ & $0.09 \pm 0.01 \mathrm{eB}$ \\
197 & $1.06 \pm 0.27 \mathrm{cdA}$ & $1.04 \pm 0.06 \mathrm{dA}$ \\
247 & $2.61 \pm 0.28 \mathrm{cA}$ & $2.44 \pm 0.05 \mathrm{cAB}$ \\
297 & $6.39 \pm 0.86 \mathrm{bA}$ & $6.08 \pm 0.23 \mathrm{bAB}$ \\
397 & $7.56 \pm 0.20 \mathrm{bB}$ & $8.61 \pm 0.41 \mathrm{aA}$ \\
647 & $11.0 \pm 2.59 \mathrm{aB}$ & \\
Mining soil & & \\
774 & $0.29 \pm 0.02 \mathrm{dA}$ & $0.28 \pm 0.05 \mathrm{eA}$ \\
\hline
\end{tabular}

Mean values and standard deviation of three replicates are shown. Different letters indicate statistically significant differences at $p<0.05$ based on ANOVA. The different capital letter in each line represents a significant difference under the same V level but in different soils. The different small letter in each row represents a significant difference in the same soils but under different $\mathrm{V}$ levels 
the mobility and bioavailability of $\mathrm{V}$ in soils. Notably, we observed significantly strong and positive correlations between the concentration of water-extractable $\mathrm{V}$ and $\mathrm{V}(\mathrm{V})$ in the soils of all treatments $(r=0.95, p=0.001)$, indicating that the mobility and bioavailability of $\mathrm{V}$ in the soils were mainly determined by the pool size of $\mathrm{V}(\mathrm{V})$ in soils instead of total soil V. Water and mild extraction reagents cannot extract or leach $\mathrm{V}$ in soils effectively, due to the significantly higher proportion of V(IV) in soils, which is mainly due to $\mathrm{VO}^{2+}$ incorporation into the lattice structure of soil minerals (Gehring et al. 1993; Taylor and Giles 1970). Baken et al. (2012) showed that geogenic V was less soluble than added $\mathrm{V}$ and that soluble $\mathrm{V}$ in soils was predominantly $\mathrm{V}(\mathrm{V})$.

The influence of soil vanadium on rape biomass

The results of pot experiments demonstrated that the growth of rape was strongly influenced by $\mathrm{V}$ in soils, and the root, stem, leaf and seed biomass all decreased with an increasing concentration of $\mathrm{V}$ in the agricultural soil (Table 3). The total biomass of rape was reduced by 27.0 and $62.9 \%$ compared with the control ( $4.48 \mathrm{~g}$, dry weight) when the $\mathrm{V}$ concentration in the agricultural soils reached 197 and $247 \mathrm{mg} \mathrm{V} \mathrm{kg}^{-1}$, respectively (Table 3 ). Toxic symptoms attributed to the suppression of chlorophyll biosynthesis became apparent in the soils at 297 and $397 \mathrm{mg} \mathrm{V} \mathrm{kg}^{-1}$, indicated by yellowing and withering of the leaves. Moreover, leaf yellowing and withering occurred earlier at higher V concentrations. Similarly, a decrease in the number of chloroplasts and a disorganisation of thylakoids was observed in Phaseolus vulgaris leaves as $\mathrm{V}$ supply increased (Saco et al. 2012). In the agricultural soil, the total rape biomass was minimal ( 0.13 and $0.01 \mathrm{~g}$, dry weight) at $297-397 \mathrm{mg} \mathrm{V} \mathrm{kg}^{-1}$, and no rape growth was observed at $647 \mathrm{mg} \mathrm{V} \mathrm{kg}^{-1}$. The inhibition of plant growth by elevated concentrations of $\mathrm{V}$ in soils agrees well with the previous finding that growth of green Chinese cabbage was inhibited in contaminated soils at $\mathrm{V}$ concentrations between 153 and $253 \mathrm{mg} \mathrm{V} \mathrm{kg}{ }^{-1}$, and the growth of approximately $80 \%$ of green Chinese cabbage plants decreased in soils at $553 \mathrm{mg} \mathrm{V} \mathrm{kg}^{-1}$ (Xiao et al. 2012) demonstrated that $\mathrm{V}$ inhabited alfalfa growth at $100 \mathrm{mg} \mathrm{V} \mathrm{kg}^{-1}$ and the total biomass of alfalfa decreased by more than $95 \%$ in soils exceeding $400 \mathrm{mg} \mathrm{V} \mathrm{kg}^{-1}$.

We observed a significantly higher total biomass of rape planted in the mining soil (4.99 g dry weight) than in all agricultural soils, although the total V concentration in the mining soil was the highest in this study. Rape biomass had a negative relationship with water-extractable $\mathrm{V}$ and a significantly negative correlation with $\mathrm{V}(\mathrm{V})(r=-0.92, p=0.01)$, but not with total $\mathrm{V}$ or $\mathrm{V}(\mathrm{IV})$ in all soils at the seedling stage (Fig. 2a). Water-extractable $\mathrm{V}$ and $\mathrm{V}(\mathrm{V})$ are apparently much better indicators than V(IV) and total V to reflect growth inhibition caused by $\mathrm{V}$ in soils.

The concentration of vanadium in rape

The concentrations of $\mathrm{V}$ in seeds were all below the method detection limit $\left(0.01 \mathrm{mg} \mathrm{V} \mathrm{kg}{ }^{-1}\right)$, whereas the leaves and stems contained maximum concentrations of $\mathrm{V}$ of 0.63 and $1.56 \mathrm{mg} \mathrm{kg}^{-1}$, respectively (Table 3 ). The concentration of $\mathrm{V}$ in roots was much higher, up to $6.46 \mathrm{mg} \mathrm{kg}^{-1}$. Thus, the $\mathrm{V}$ concentrations in rape decreased in the sequence: root $>>$

Table 3 Concentrations of vanadium (V) in the seeds, leaves, roots, stems and biomass of Brassica juncea L. growing in agricultural soils at different levels of $\mathrm{V}$ and in the mining soil

\begin{tabular}{|c|c|c|c|c|c|c|c|c|c|}
\hline \multirow{2}{*}{$\begin{array}{l}\text { Soil } \\
\left(\mathrm{mg} \mathrm{V} \mathrm{kg}^{-1}\right)\end{array}$} & \multicolumn{5}{|c|}{ Biomass (g dry weight/ three pots) ${ }^{\mathrm{a}}$} & \multicolumn{4}{|c|}{ Vanadium concentration $\left(\mathrm{mg} \mathrm{V} \mathrm{kg}^{-1}\right)^{\mathrm{b}}$} \\
\hline & Total & Stems & Roots & Leaves & Seeds & Stems & Roots & Leaves & Seeds \\
\hline \multicolumn{10}{|c|}{ Agricultural soil } \\
\hline 147 & 4.48 & 2.53 & 0.66 & 1.22 & 0.07 & $<\mathrm{DL}$ & 0.04 & $0.02 \pm 0.001$ & $<\mathrm{DL}$ \\
\hline 197 & 3.27 & 1.38 & 0.77 & 1.00 & 0.13 & $0.54 \pm 0.37$ & 4.58 & $0.16 \pm 0.04$ & $<\mathrm{DL}$ \\
\hline 247 & 1.66 & 0.68 & 0.36 & 0.62 & - & 1.56 & 6.47 & 0.63 & - \\
\hline 297 & 0.13 & - & - & - & - & - & - & - & - \\
\hline 397 & 0.01 & - & - & - & - & - & - & - & - \\
\hline 647 & - & - & - & - & - & - & - & - & - \\
\hline Mining soil & & & & & - & & & & \\
\hline 774 & 4.99 & 2.90 & 0.75 & 1.33 & - & $0.10 \pm 0.03$ & $0.56 \pm 0.14$ & $0.14 \pm 0.04$ & - \\
\hline
\end{tabular}

Means and standard deviations of three digestion replicates are shown for data containing standard deviations

"-_" not determined, $<D L$ below the limit of detection $0.01 \mathrm{mg} \mathrm{V} \mathrm{kg}^{-1}$

${ }^{\text {a }}$ Sum from three pot replicates

${ }^{\mathrm{b}}$ Mean values and standard deviations of three digestion replicates are shown

If no standard deviations are shown, plant biomass was insufficient for replicate analysis 

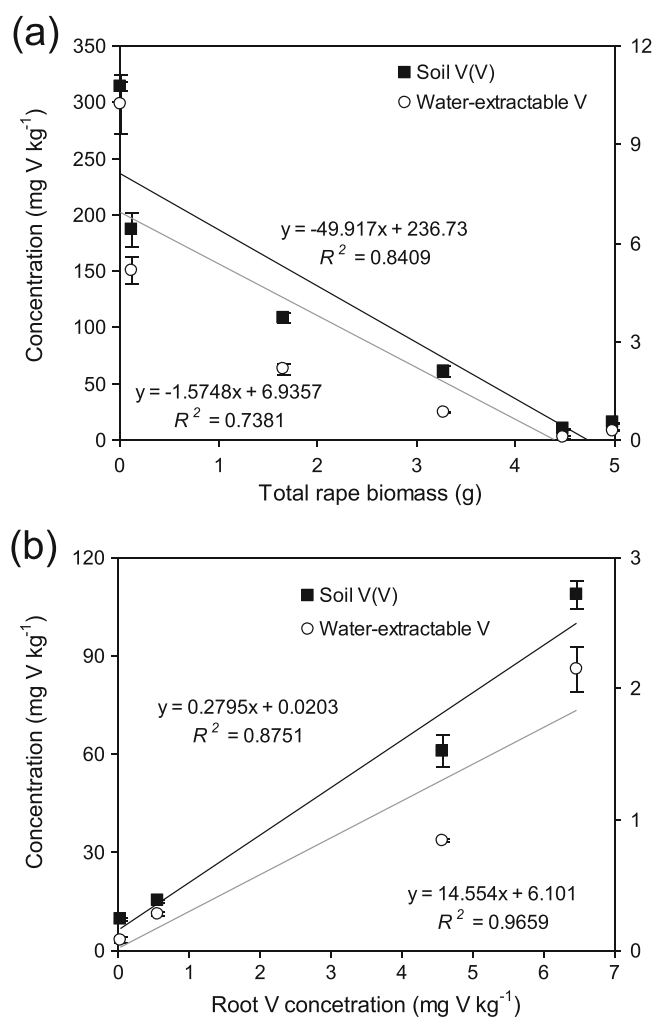

Fig. 2 The correlations between concentrations of pentavalent vanadium (V(V)) (right axis) and water-extractable vanadium (left axis) in soils at the rape seedling stage and (a) total biomass of rape and (b) total vanadium concentrations in roots of all treatments. Error bars show the standard deviations of three replicates

stem $>$ leaf $>$ seed (Table 3 ), which suggests that most $\mathrm{V}$ accumulated in roots and only small amounts of soil $\mathrm{V}$ were translocated to the aboveground tissues. Terrestrial plants have developed mechanisms either to accumulate or exclude toxic substances taken up from soils. For exclusion, toxic substances are translocated from the roots to the other parts of plants, thereby preventing their over-accumulation in roots (Brackhage et al. 2014). For accumulation, toxic substances are preferentially converted to their insoluble forms and are subsequently distributed to certain parts of organs and tissues. The high concentration of $\mathrm{V}$ in roots compared with that in stems and leaves suggests that the root is the major organ that binds $\mathrm{V}$ in rape. Many plants are known to preferentially accumulate $\mathrm{V}$ in the roots to prevent or minimise $\mathrm{V}$ toxicity to the plants, e.g. Brassica juncea, B. chinensis (Hou et al. 2013), B. rapa (Tian et al. 2014), Artemisia vulgarism, Polygonum cuspidatum, Phragmites australis, Rhus copallinum, Betula populifoli and Populus deltoides (Qian et al. 2014) (Table 4). The translocation of $\mathrm{V}$ from the root to the aboveground parts might be due to the self-protective function of plants to impede upward translocation (Beveridge 1999). Heavy metals can cause several toxic symptoms in plants and algae, e.g. growth retardation, photosynthetic inhibition, the induction and inhibition of enzymes and the generation of oxidative stress (Di Toppi et al. 2003). For V, V(V) is known to mediate free radical reactions and consequently cause oxidative stress (Zhang et al. 2003). The first symptom observed in V-stressed rape (in the soils at $247 \mathrm{mg} \mathrm{V} \mathrm{kg}^{-1}$ ) was browning of the roots, which has been reported to reflect oxidative stress as a defence mechanism by plants towards pathogens or contaminants (Thipyapong et al. 2004; Yang et al. 2014a).

The concentrations of $\mathrm{V}$ in stems and leaves generally increased slightly with increasing concentrations of $\mathrm{V}$ in agricultural soils, reaching 0.54 and $0.16 \mathrm{mg} \mathrm{V} \mathrm{kg}^{-1}$ in the soil at $197 \mathrm{mg} \mathrm{V} \mathrm{kg}^{-1}$, respectively (Table 3). The concentration of $\mathrm{V}$ in stems and leaves at a soil concentration of $247 \mathrm{mg} \mathrm{V} \mathrm{kg}^{-1}$ increased to three- and four-fold higher than those in the soil at $197 \mathrm{mg} \mathrm{V} \mathrm{kg}^{-1}$, respectively. The concentration of $\mathrm{V}$ in roots was low in the mining and untreated agricultural soil (0.04 and $0.56 \mathrm{mg} \mathrm{kg}^{-1}$, respectively) and increased with increasing concentrations of soil $\mathrm{V}$ to reach $6.47 \mathrm{mg} \mathrm{V} \mathrm{kg}^{-1}$ in the soil at $247 \mathrm{mg} \mathrm{V} \mathrm{kg}^{-1}$, which is 1.5 -fold higher than that in the soils at $197 \mathrm{mg} \mathrm{V} \mathrm{kg}^{-1}$. Although the total $\mathrm{V}$ concentration in the mining soil was higher than that in the agricultural soils, the $\mathrm{V}$ concentration in different parts of rape plants in mining soils was significantly lower than that for tissues of plants growing in all agricultural soils $(p<0.05)$, suggesting that $\mathrm{V}$ accumulation in plants is not determined by the total V concentration in the soil. Studies of V uptake and translocation in the dominant plants on a US urban coastal brownfield site revealed that the soil-labile $\mathrm{V}$ content strongly affected V accumulation (Qian et al. 2014). In this study, the $\mathrm{V}$ accumulation in roots and $\mathrm{V}$ translocation in the aboveground parts of rape were strongly associated with $\mathrm{V}(\mathrm{V})$ and water-extractable $\mathrm{V}$ in the soil, as indicated by the significantly positive correlation between the $\mathrm{V}$ concentration in the root and $\mathrm{V}(\mathrm{V})$ in the soil $(r=0.98, p=0.023)$ and by the positive relationship between water-extractable $\mathrm{V}$ in all soils at the harvesting stage of rape (Fig. 2b).

Vanadium root bioconcentration and translocation factors for rape

The estimated root bioconcentration factor of rape based on the total soil $\mathrm{V}$ ranged from 0.03 to $2.25 \%$ (Table 4). Taking the soil $\mathrm{V}(\mathrm{V})$ and water-extractable $\mathrm{V}$ into account, which substantially entered the soil-plant interaction of $\mathrm{V}$ for calculation, the root bioconcentration factors increased (to $0.41-$ 5.68 and $32.4-432 \%$, respectively). The ability of rape to accumulate soil $\mathrm{V}$ in roots appeared to be comparably low, since the previously published root bioconcentration factors for woody and herbaceous plants were at least a level of magnitude higher (Table 4). For example, the root bioconcentration factors of Chinese cabbage estimated from total soil V and water-extractable $\mathrm{V}$ were 40 and $6983 \%$, respectively (Tian et al. 2014; Xiao et al. 2012) (Table 4). The root bioconcentration factors calculated from labile $\mathrm{V}$ in soils $\left(\mathrm{HNO}_{3}\right.$ extractable) were between 56 and $1080 \%$ for 


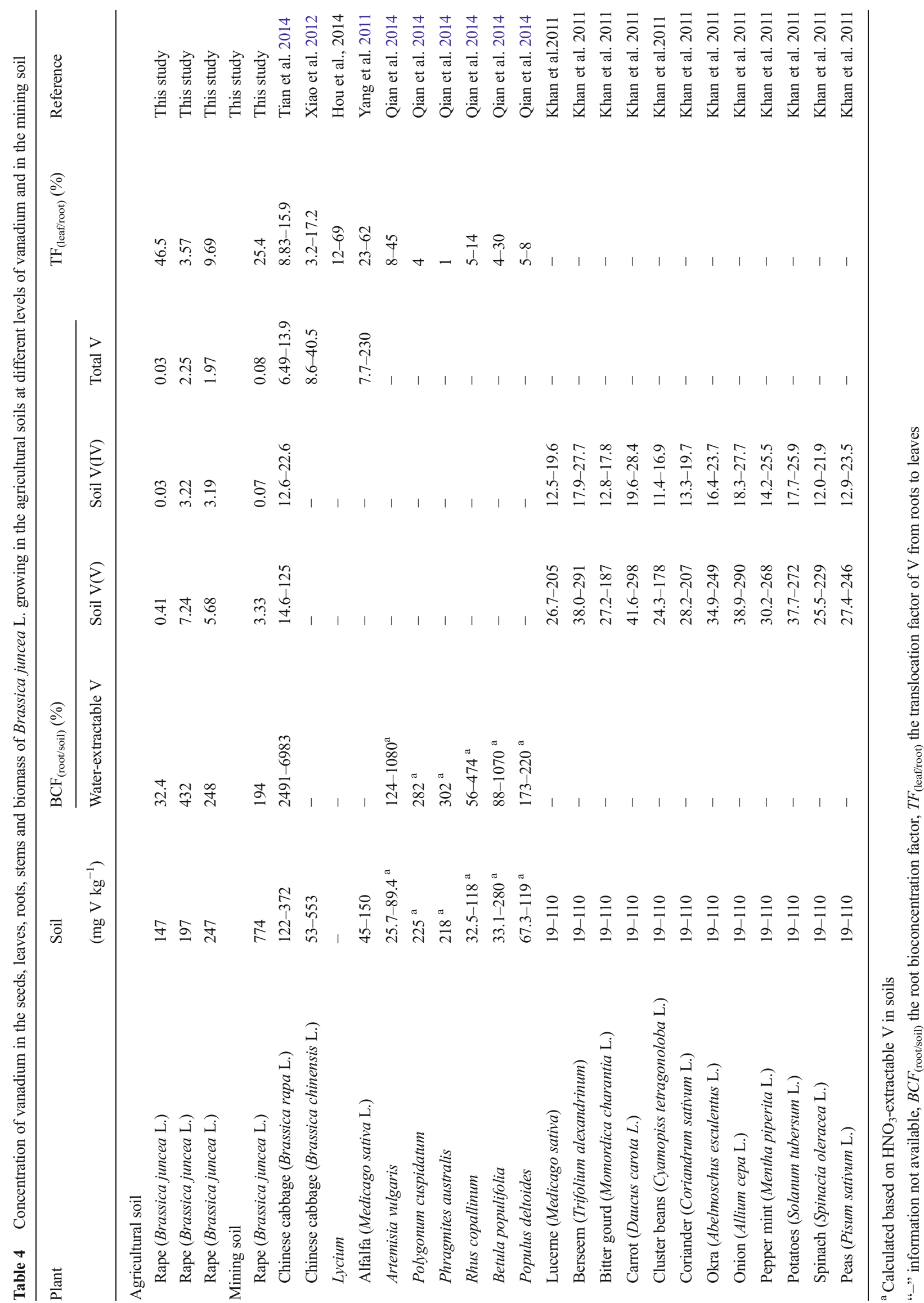


Artemisia vulgaris, Polygonum cuspidatum, Phragmites australis, Rhus copallinum, Betula populifolia and Populus deltoides (Qian et al. 2014). Apparently, rape has developed different mechanisms for the uptake and accumulation of $\mathrm{V}$ in soils, as its root bioconcentation factors were considerably low; further research is required to elucidate the relevant mechanisms. The translocation factor of $\mathrm{V}$ from the roots to the aboveground tissues of rape was between 3.57 and $46.5 \%$, which is similar in range to that of other plants documented in previous studies (Table 4). Therefore, rape is as effective as other plants in excluding $\mathrm{V}$ from roots.

\section{Conclusion}

The results from this study clearly indicate that total $\mathrm{V}$ cannot cause the toxicity of $\mathrm{V}$ to plants in soils, which is better reflected by soil V(V) and water-extractable V. Tetravalent V in soils appears to be little associated with the $\mathrm{V}$ plant-soil interaction. The bioavailability of added $\mathrm{V}$ is higher than that of geogenic $\mathrm{V}$ due to the different chemical forms and binding states of $\mathrm{V}$ presented in soils. Vanadium was taken up by rape mainly from the rhizosphere soil in the form of $V(V)$ and accumulated predominantly in roots. However, rape roots could not accumulate as much $\mathrm{V}$ as most plants reported in the literature, as indicated by a root bioconcentration factor that was one order of magnitude lower. Rape has a similar ability to that of other plants to limit the further distribution of $\mathrm{V}$ to the aboveground tissues. Vanadium was never detected in seeds in all treatments, indicating the low probability of $\mathrm{V}$ transfer from the soil to human beings via consumption of rapeseed-based food materials such as rape oil.

Acknowledgments This research was supported by National Natural Science Foundation of China (41101484), China-EU Science \& Technology Cooperation Program (2011DFA101222), Research Fund for the Doctoral Program of Higher Education of China (200806101129) and Swiss National Science Foundation (Grant No. PZ00P2_142232).

\section{References}

Anke M (2004) Vanadium - an element both essential and toxic to plants, animals and humans? Anal Real Acad Nac Farm 70:961-999

ATSRD (2012) Toxicological profile for vanadium. In: U.S. Department of Health and Human Services PHS (Hrsg.). Atlanta, Georgia, p 255

Baken S, Larsson MA, Gustafsson JP, Cubadda F, Smolders E (2012) Ageing of vanadium in soils and consequences for bioavailability. Eur J Soil Sci 63:839-847

Beveridge TJ (1999) Structures of gram-negative cell walls and their derived membrane vesicles. J Bacteriol 181:4725-4733

Brackhage C, Huang J-H, Schaller J, Elzinga EJ, Dudel EG (2014) Readily available phosphorous and nitrogen counteract for arsenic uptake and distribution in wheat (Triticum aestivum L.). Sci Rep 4
Burke IT, Mayes WM, Peacock CL, Brown AP, Jarvis AP, Gruiz K (2012) Speciation of arsenic, chromium, and vanadium in red mud samples from the Ajka spill site, Hungary. Environ Sci Technol 46: 3085-3092

Burke IT, Peacock CL, Lockwood CL, Stewart DI, Mortimer RJG, Ward MB, Renforth P, Gruiz K, Mayes WM (2013) Behavior of aluminum, arsenic, and vanadium during the neutralization of red mud leachate by hcl, gypsum, or seawater. Environ Sci Technol 47:65276535

Carlson CL, Adriano DC, Sajwan KS, Abels SL, Thoma DP, Driver JT (1991) Effects of selected trace metals on germinating seeds of six plant species. Water Air Soil Pollut 59:231-240

Di Toppi LS, Gremigni P, Pawlik-Skowrońska B, Prasad M, Cobbett C (2003) Response to heavy metals in plants: a molecular approach, Abiotic Stresses in Plants. Springer, pp. 133-156

Gehring AU, Fry IV, Luster J, Sposito G (1993) The chemical form of vanadium(iv) in kaolinite. Clay Clay Miner 41:662-667

Hou M, Hu C, Xiong L, Lu C (2013) Tissue accumulation and subcellular distribution of vanadium in Brassica juncea and Brassica chinensis. Microchem J 110:575-578

Huang JH, Kretzschmar R (2010) Sequential extraction method for speciation of arsenate and arsenite in mineral soils. Anal Chem 82: $5534-5540$

Jensen-Fontaine M, Norwood WP, Brown M, Dixon DG, Le XC (2014) Uptake and speciation of vanadium in the benthic invertebrate Hyalella azteca. Environ Sci Technol 48:731-738

Kaplan D, Sajwan K, Adriano D, Gettier S (1990) Phytoavailability and toxicity of beryllium and vanadium. Water Air Soil Pollut 53:203212

Larsson MA, Baken S, Gustafsson JP, Hadialhejazi G, Smolders E (2013) Vanadium bioavailability and toxicity to soil microorganisms and plants. Environ Toxicol Chem 32:2266-2273

Li XS, Glasauer S, Le XC (2009) Speciation of vanadium in oilsand coke and bacterial culture by high performance liquid chromatography inductively coupled plasma mass spectrometry. Anal Chim Acta 648:128-128

Lu RK (1999) Agricultural chemical analysis method of soil. Chinese agricultural science and technology. Press, Beijing

Mandiwana KL, Panichev N (2004) Electrothermal atomic absorption spectrometric determination of vanadium $(\mathrm{V})$ in soil after leaching with $\mathrm{Na}_{2} \mathrm{CO}_{3}$. Anal Chim Acta 517:201-206

Misik M, Burke IT, Reismueller M, Pichler C, Rainer B, Misikova K, Mayes WM, Knasmueller S (2014) Red mud a byproduct of aluminum production contains soluble vanadium that causes genotoxic and cytotoxic effects in higher plants. Sci Total Environ 493:883890

Nalewajko C, Lee K, Jack T (1995) Effects of vanadium on freshwater phytoplankton photosynthesis. Water Air Soil Pollut 81:93-105

Panichev N, Mandiwana K, Moema D, Molatlhegi R, Ngobeni P (2006) Distribution of vanadium( $(\mathrm{V})$ species between soil and plants in the vicinity of vanadium mine. J Hazard Mater 137:649-653

Pyrzyńska K, Wierzbicki T (2004) Determination of vanadium species in environmental samples. Talanta 64:823-829

Qian Y, Gallagher FJ, Feng H, Wu M, Zhu Q (2014) Vanadium uptake and translocation in dominant plant species on an urban coastal brownfield site. Sci Total Environ 476:696-704

Saco D, Martín S, San José P (2012) Vanadium distribution in roots and leaves of Phaseolus vulgaris: morphological and ultrastructural effects. Biol Plantarum 57:128-132

Shafer MM, Toner BM, Oyerdier JT, Schauer JJ, Fakra SC, Hu S, Herner JD, Ayala A (2012) Chemical speciation of vanadium in particulate matter emitted from diesel vehicles and urban atmospheric aerosols. Environ Sci Technol 46:189-195

Taylor R, Giles J (1970) The association of vanadium and molybdenum with iron oxides in soils. J Soil Sci 21:203-215 
Teng Y, Jiao X, Wang J, Xu W, Yang J (2009) Environmentally geochemical characteristics of vanadium in the topsoil in the Panzhihua mining area, Sichuan Province, China. Chin J Geochem 28:105-111

Teng YG, Yang J, Sun ZJ, Wang JS, Zuo R, Zheng JQ (2011) Environmental vanadium distribution, mobility and bioaccumulation in different land-use districts in Panzhihua region, SW China. Environ Monit Assess 176:605-620

Thipyapong P, Melkonian J, Wolfe DW, Steffens JC (2004) Suppression of polyphenol oxidases increases stress tolerance in tomato. Plant Sci 167:693-703

Tian L, Yang J, Alewell C, Huang J-H (2014) Speciation of vanadium in Chinese cabbage Brassica rapa L. and soils in response to different levels of vanadium in soils and cabbage growth. Chemosphere 111: 89-95

Vwioko D, Anoliefo G, Fashemi S (2006) Metal concentration in plant tissues of Ricinus communis L. (castor oil) grown in soil contaminated with spent lubricating oil. J Appl Sci Environ Manag 10:127-134

Wang JF, Liu Z (1999) Toxicity of vanadium on soybean seedlings and relationship with soil characteristics. Soil Environ Sci China 8:1-4
Wong J, Lytle FW, Messmer RP, Maylotte DH (1984) K-edge absorptionspectra of selected vanadium compounds. Phys Rev B 30:5596-5610

Xiao XY, Yang M, Guo ZH, Luo YP, Bi JP (2012) Permissible value for vanadium in allitic udic ferrisols based on physiological responses of green Chinese cabbage and soil microbes. Biol Trace Elem Res 145:225-232

Yang J, Teng Y, Wang J, Li J (2011) Vanadium uptake by alfalfa grown in V-Cd-contaminated soil by pot experiment. Biol Trace Elem Res 142:787-795

Yang J, Huang J-H, Lazzaro A, Tang Y, Zeyer J (2014a) Response of soil enzyme activity and microbial community in vanadium-loaded soil. Water Air Soil Pollut 225:1-10

Yang J, Tang Y, Yang K, Rouff AA, Elzinga EJ, Huang JH (2014b) Leaching characteristics of vanadium in mine tailings and soils near a vanadium titanomagnetite mining site. J Hazard Mater 264:498-504

Zhang Z, Leonard SS, Huang C, Vallyathan V, Castranova V, Shi $X$ (2003) Role of reactive oxygen species and MAPKs in vanadate-induced $\mathrm{G}_{2} / \mathrm{M}$ phase arrest. Free Radic Biol Med $34: 1333-1342$ 